\title{
Pszichoszomatikus tünetek előfordulási gyakorisága 8-17 éves magyar gyermekek körében
}

\author{
Fehér Piroska - Annár Dorina - Zsákai Annamária dr. - Bodzsár Éva dr. \\ Eötvös Loránd Tudományegyetem, Embertani Tanszék, Budapest
}

Bevezetés: A pszichoszomatikus tünetek gyakorisági mintázatát számos tényező (életkor, nem, egészségi állapot) befolyásolja a teljes emberi életciklus során. A pszichoszomatikus tüneteknek a korcsoportra jellemző, átlagostól nagyobb gyakorisága hozzájárulhat az életminőség romlásához. A gyermekkorban jelentkező pszichoszomatikus tünetek hatással lehetnek a felnőttkori egészségi állapotra.

Célkitüzés: Iskoláskorú és pubertáskorú gyermekek ( $\mathrm{n}=13$ 331; életkor: 8-17 év) körében a pszichoszomatikus tünetek előfordulási gyakoriságának felmérése és az egyes pszichoszomatikus tünetek gyakorisági mintázatát befolyásoló testszerkezeti, pszichoszociális és életmódbeli tényező́k azonosítása.

Módszer: Vizsgálatunkban a Második Országos Növekedésvizsgálatban részt vett gyermekek egyik almintájának pszichoszomatikus státuszát elemeztük. A pszichoszomatikus tünetek gyakoriságát a Haugland-féle módszerrel becsültük. A gyermekek testszerkezetének jellemzésére abszolút és relatív testdimenziókat, a tápláltsági állapotot, a pszichoszociális státusz jellemzésére az önértékelés és az énkép komponenseit, az egészségi állapot mutatóit, a szocioökonómiai háttér tényezőit, az életmód jellemzésére pedig a fizikai aktivitási mintázat tényezőit használtuk fel. Eredmények: A pszichoszomatikus tünetek gyakorisága nőtt az életkorral. A leányoknál gyakrabban fordultak elő pszichoszomatikus tünetek. A leányok esetében a tápláltsági állapot, az önértékelés és az iskolai sikeresség a pszichoszomatikus tünetek mintázatának legfontosabb befolyásoló tényezői, ezzel szemben a fiúk esetében a pszichoszomatikus tünetek mintázatát a legjelentősebben a fizikai aktivitási szint és a szocioökonómiai háttér tényezői befolyásolják.

Következtetések: A pszichoszomatikus tünetek gyakoriságát jelentős mértékben befolyásolja a nem, az életkor, a testszerkezeti tényező́k, az egészségi állapot és a pszichoszociális státusz.

Orv Hetil. 2019; 160(12): 464-472.

Kulcsszavak: pszichoszomatikus tünetek, makro- és mikrokörnyezeti tényezők, egészségi állapot, tápláltsági állapot

\section{The prevalence of psychosomatic complaints among 8-17-year-old Hungarian children}

Introduction: Subjective health complaints are common among children as well. Age, gender, health status, etc. can modify the prevalence, intensity, frequency and the dimensions of the psychosomatic complaints.

Aim: The main purposes were to analyse the frequency pattern of psychosomatic complaints in children as well as to study the influence of physical status and lifestyle factors on psychosomatic status.

Method: The subjects of the present analysis represented a random sample of the Hungarian National Growth Study $(\mathrm{n}=13331 ; 8-17$-year-old). The three clusters of the health complaints were somatic, psychological and sleeping disorders. The psychosomatic status of 8-17-year-old children was analysed by dividing them into subgroups of experiencing the subjective health complaints often (weekly or more often), on an average level or rarely. Frequency distributions were examined for each subjective health complaint. Multinomial logistic regression analysis was applied to reveal the relationship between the frequency pattern of psychosomatic complaints and the hypothesized predictive factors.

Results: The prevalence of the psychosomatic complaints increased by age, and girls reported more symptoms than boys. Subjective health status, nutritional status, body image, academic achievement, stature, body mass and socioeconomic status influenced the frequency pattern of psychosomatic complaints in girls, while physical activity, selfesteem, socioeconomic status and subjective health status in boys.

Conclusions: Age, gender, socioeconomic status and psychosocial status can affect the frequency pattern of the psychosomatic complaints. 
Keywords: psychosomatic complaints, subjective health status, nutritional status, macro- and micro-environmental factors

Fehér P, Annár D, Zsákai A, Bodzsár É. [The prevalence of psychosomatic complaints among 8-17-year-old Hungarian children]. Orv Hetil. 2019; 160(12): 464-472.

(Beérkezett: 2018. november 21.; elfogadva: 2018. december 4.)

A betegségek kialakulásában, kiújulásában és súlyosbodásában a genetikai hajlam mellett az életmód, a stressz, a környezeti tényezők jelentős szerepe megkérdőjelezhetetlen. A pszichoszomatikus jelzőt olyan tünetekre, betegségekre, folyamatokra használhatjuk, melyekben a testi és pszichoszociális tényezők egyaránt szerepet játszanak. A pszichoszomatikus tünetek hátterében nem áll szervi elváltozás, sőt napjainkban széles körben elterjedt az az elképzelés is, miszerint minden betegség etiológiájában, patogenezisében és lefolyásában szerepet játszanak pszichoszociális tényező́k is a biológiai okok mellett. A tünetekre jellemzó, hogy hosszabb ideje fennállnak, változatos formában jelentkezhetnek, hajlamosak a kiújulásra, ezáltal a beteg életminőségét jelentős mértékben ronthatják.

Pikó és mtsai 18-31 éves magyar egyetemisták körében végzett vizsgálatából kiderült, hogy a pszichoszomatikus tünetek közül az alvászavarok, a krónikus fáradtság és a hátfájdalom fordult elő a leggyakrabban mindkét nem esetén [1]. A nőknél nagyobb arányban fordultak elő a tünetek, mint a férfiaknál. Azok a hallgatók, akik roszszabbra értékelték általános egészségi állapotukat, több pszichoszomatikus tünetet éltek át. A pszichoszomatikus tünetek nemcsak serdülőkortól kezdve jelentkezhetnek, hanem már gyermekkorban megjelenhetnek. A gyermekkori egészségi problémák a felnôttkori életminőségre is hatással lehetnek. A tünetek hátterében a stresszel szembeni megküzdési stratégiák hiánya, perfekcionista személyiségvonások, családi konfliktusok, megnövekedett iskolai elvárások, traumák, a társas kapcsolatokban felmerülő nehézségek állhatnak.

A pszichoszomatikus tünetek gyakorisága gyermekkorban növekedik az életkor előrehaladtával [2]. A tünetek a leányoknál gyakrabban fordulnak elő, mint a fiúknál $[3,4]$. A pszichoszomatikus tünetek átlagos előfordulási gyakorisága 10-25\% [5]. Az epidemiológiai tanulmányok azt mutatják, hogy a gyermekek és pubertáskorúak 10-30\%-a számol be heti rendszerességgel jelentkező fejájásról $[6,7], 10-25 \%$-uk panaszkodik rekurrens hasi fájdalomról $[2,8,9]$, és 5-20\%-uknál fordulnak elő musculoskeletalis jellegú fájdalmak [2, 10]. A pszichoszomatikus tünetek a hátrányos szocioökonómiai státuszú családokban nevelkedő gyermekeknél gyakrabban fordulnak elő [11].

A gyermekgyógyászatban a pszichoszomatikus tünetek összefüggésben állnak a pszichiátriai komorbiditás (depresszió, szorongás) rizikójának növekedésével, csalá- di konfliktusokkal, iskolai teljesítménycsökkenéssel vagy iskolai hiányzással [12]. A betegek panaszaikkal először a háziorvost keresik fel, aki szakorvosi kontrollra küldi tovább őket. A tünetek aspecifikus természete nehezíti a diagnózis felállítását, az átfogó kivizsgálás hosszú időt vehet igénybe, a betegek lemorzsolódhatnak, belefáradhatnak a sorozatos vizsgálatokba. Az egészségügyi ellátórendszerben, ha nem sikerül a tünetek hátterében szervi okot azonosítani, a háziorvos a betegeket pszichoterapeutához, pszichológushoz utalja. A pszichoszomatikus tünetek és betegségek eredményes kezelésében kulcsfontosságú az orvos-beteg kommunikáció minősége. A tapasztalat azt mutatja, hogy a betegek egy részéből a tünetek pszichés aspektusa a kezelőorvos iránt bizalmatlanságot vált ki, előfordul, hogy más orvoshoz fordulnak segítségért, vagy öngyógyításba kezdenek [13]. A pszichoszomatikus tünetek diagnosztizálása és kezelése problematikus, az orvos és a beteg részéról is körültekintést, türelmet és időt követel, ami a jelen egészségügyi ellátórendszer hiányosságai miatt sok esetben nem tud megvalósulni. A tünetek kezelésére egyéni, csoport- vagy kognitív terápia javasolható, de egyre inkább előtérbe kerültek az olyan terápiás irányzatok is, mint a müvészet-, tánc- vagy mozgásterápia.

Vizsgálatunk célkitüzése volt, hogy 8-17 éves gyermekek körében a pszichoszomatikus tünetek mintázatát befolyásoló testszerkezeti, pszichoszociális, életmódbeli tényezőket azonosítsuk. Célkitüzésünk megvalósításához a Második Országos Növekedésvizsgálatban [14] részt vett gyermekek egy random módon választott almintájának pszichoszomatikus státuszát elemeztük. Korábbi elemzésünk igazolta a pszichoszomatikus és a tápláltsági állapot közötti összefügggést a vizsgált életkori intervallumban [15], jelen elemzésünkkel pedig célunk, hogy a pszichoszomatikus panaszok gyakoriságával kapcsolatot mutató további háttértényezóket is feltárjuk.

Feltételeztük, hogy (1) a pszichoszomatikus tünetek előfordulási gyakorisága az életkor előrehaladtával nő, és (2) gyakrabban érinti a leányokat, mint a fiúkat, (3) a pszichoszomatikus panaszok különböző csoportjai (szomatikus, pszichés tünetek, alvási nehézségek) előfordulási gyakoriságának valószínúségével a vizsgált életmódbeli, testszerkezeti tényezók eltérő csoportjai állnak szoros kapcsolatban, (4) a pszichoszomatikus panaszok gyakoriságára hatással lévő környezeti és testszerkezeti tényezók csoportjai a két nemnél különbözőek, (5) a testük szerkezetével, illetve életükkel elégedetlenebb gyerme- 
kek esetében a pszichoszomatikus panaszok gyakrabban fordulnak elő, (6) az egészségi állapot mutatói és a pszichoszomatikus panaszok gyakorisága között szoros a kapcsolat, (7) a jó szocioökonómiai háttérben nevelkedő gyermekek ritkábban élnek át pszichoszomatikus tüneteket, (8) a tanulmányi eredménynek a pszichoszomatikus panaszok gyakoriságára gyakorolt hatása a leányok esetében jelentősebb, mint a fiúknál.

\section{Vizsgált személyek és alkalmazott módszerek}

\section{Minta}

Vizsgálati célkitűzésünk megvalósításához a Második Országos Növekedésvizsgálatban részt vett gyermekek egy random módon választott almintájának $(n=13331$ fó, 1. táblázat) pszichoszomatikus státuszát elemeztük. A minta nemek szerinti megoszlása 6680 fiú (50,1\%) és 6651 leány $(49,9 \%)$. A vizsgált életkori intervallum magában foglalja a prepubertás (8-10 éves kor; 26,5\%), a pubertás (11-14 éves kor; $52,3 \%)$ és a posztpubertás időszakát (15-17 éves kor; 21,1\%), amely életkori szakaszok a biológiai, pszichés és szociális fejlődés legérzékenyebb időszakai az emberi élet során. Az országos reprezentatív növekedésvizsgálat során a 3-18 éves (n = 25 151) magyar gyermekek testfejlettségi és tápláltsági állapotának, pszichoszociális és mentális egészségi státuszának, illetve a gyermekek életmódját jellemző tényezóknek (táplálkozási szokásaik, fizikai aktivitásuk tényezői) a felmérésére került sor [14].

\section{Módszer}

A gyermekek testi fejlettségének becsléséhez szükséges antropometriai vizsgálatokat a nemzetközi gyakorlatban használt módszerekkel és múszerekkel végeztük el [16, 17]. A gyermekek testösszetevő komponenseit (csont-, izom-, zsír- és zsigertömeg) a Drinkwater-Ross-féle

1. táblázat |A vizsgált minta életkor és nem szerinti megoszlása

\begin{tabular}{lcc}
\hline Életkor (év) & Fiúk & Leányok \\
\hline 8 & 539 & 595 \\
9 & 602 & 611 \\
10 & 571 & 618 \\
11 & 659 & 718 \\
12 & 728 & 788 \\
13 & 682 & 726 \\
14 & 594 & 590 \\
15 & 762 & 732 \\
16 & 822 & 696 \\
17 & 721 & 577 \\
\hline Együtt & 6680 & 6651 \\
\hline
\end{tabular}

négykomponensü antropometriai módszer alapján becsültük [18]. A testösszetevố komponensek relatív menynyiségének meghatározásához az abszolút mennyiségüknek a testtömeg százalékában kifejezett értékét határoztuk meg.

Az életmód tényezőinek (a fizikai aktivitás rendszeressége, intenzitása, időtartama), a pszichoszociális és az egészségi állapot tényezőinek, illetve az iskolai eredményesség tényezőinek felmérésére az almintába sorolt gyermekektől személyes interjúk során kérdőíves formában gyűjtöttünk adatokat.

\section{Statisztikai elemzés}

A pszichoszomatikus panaszok gyakorisága és a vizsgált életmód és a pszichoszociális tényezők közötti kapcsolatrendszer jellemzésére többtényezős logisztikus regreszsziós elemzést végeztünk el. Az elemzést a két nemre vonatkozóan külön-külön hajtottuk végre. A regressziós elemzést a testi és a pszichés tüneteknek, illetve az alvási nehézségek tüneteinek három csoportjában külön végeztük el, ebben az esetben is feltételezve, hogy más-más tényezők mutathatnak kapcsolatot a testi és a pszichés tünetek, illetve az alvási nehézségek tünetei csoportjainak gyakoriságával. A Haugland-féle módszernek megfelelően az egyes pszichoszomatikus tünetek és a három tünetcsoport esetén is a panaszokat gyakran, átlagos gyakoriságban és ritkán átélők csoportjait alakítottuk ki [19]. A testi tünetek közé a fejfájás, a hasfájás és a szédülés tartozott, a pszichés tünetek csoportjába a kedvetlenség, az ingerlékenység és az idegesség került, míg az alvási nehézségek csoportjába soroltuk, ha a gyermek nehezen tud elaludni, gyakran felébred éjjel, és fáradtan ébred. A pszichoszomatikus tünetek életkori mintázatának vizsgálatához három életkori csoportot különítettünk el. Az első korcsoportba a 8-10 éveseket, a második korcsoportba a 11-14 éveseket, a harmadik korcsoportba a 15-17 éveseket soroltuk.

A regressziós elemzésbe folyamatos eloszlású, a pszichoszomatikus panaszok gyakorisági mintázatát magyarázó tényezőkként a következők kerültek bevonásra: életkor (év), a testszerkezet mutatói közül a testmagasság $(\mathrm{cm})$, a testtömeg $(\mathrm{kg})$, a relatív zsírtömeg $(\%)$, a relatív izomtömeg (\%), a relatív csonttömeg (\%), az általános egészségi állapot felmérésére használt mutatók közül a szisztolés és diasztolés vérnyomás (Hgmm) és a pulzus (ütésszám/perc). A diszkrét eloszlású becslő tényezők közül a következő tényezőknek a pszichoszomatikus tünetek gyakoriságával mutatott kapcsolatát vizsgáltuk: tápláltsági állapot (a testtömegindex Cole és mtsai [20, 21] által meghatározott életkori határértékei alapján történt besorolással: alultáplált, normál tápláltsági állapotú, túlsúlyos és kövér tápláltsági állapotú kategóriák), a szubjektív egészségi állapot (kitűnő, jó, megfelelő, rossz alcsoportok), az élettel való elégedettség foka (a Cantril és mtsai [22] által kidolgozott skála alapján az életüket jónak, átlagosnak és rossznak minősítők alcsoportjait el- 
különítve), a szocioökonómiai háttér tényezői közül a szocioökonómiai státusz alapján kialakított rossz, átlagos és jó szocioökonómiai státuszú alcsoportokba történt besorolással [23]), a településnagyság (10 000 fónél nagyobb, illetve kisebb lélekszámú településkategóriákba történő besorolással), a települések gazdasági-társadalmi besorolása (hátrányos helyzetű, illetve nem hátrányos helyzetü kistérségek), a pszichés státusz mutatói közül az önértékelési státusz becslésére bevezetett úgynevezett Tennessee-féle énképskála $[24,25]$ alapján meghatározott testkép és teljes énkép (negatív, átlagos és pozitív énkép-kategóriákba való besorolással), az iskolai sikerességet becsülő átlagos tanulmányi eredmény (humán, reál és készségtárgyak összesített átlaga alapján az iskolában az átlagostól rosszabbul, átlagosan, az átlagostól jobban teljesítő kategóriákba történő besorolással), fizikai aktivitási szint (a habituális fizikai aktivitás rendszeressége, intenzitása, időtartama alapján fizikailag aktívak és inaktívak, illetve átlagos aktivitásúak alcsoportjait különítettük el).

A regressziós elemzés értékelésekor a likelihood elméleten alapuló khi-négyzet $\left(\chi^{2}\right)$-próbát alkalmaztuk az illeszkedésvizsgálat során, 5\%-os szignifikanciaszinten (eredményeink bemutatásakor csak a pszichoszomatikus panaszok gyakorisági mintázatával szignifikáns kapcsolatban álló tényezők kerültek feltüntetésre a táblázatokban). A vizsgált tényezők regressziós együtthatójából (B) számolt, úgynevezett esélyhányados $[\exp (\mathrm{B})]$ megmutatja, hogy folytonos eloszlású magyarázó változó esetén egyegységnyi változás hányszorosára növeli a becsült esemény (gyakori pszichoszomatikus panaszok) bekövetkeztének valószínűségét, illetve diszkrét eloszlású magyarázó változó esetén a vizsgált kategória esetében hányszorosa a becsült esemény bekövetkeztének valószínűsége a referenciakategóriához képest. A statisztikai értékelést a SPSS 14.0 program (SPSS Inc., Chicago, IL, Egyesült Államok) segítségével végeztük.

\section{Vizsgálati eredmények és értékelésük}

\section{A pszichoszomatikus panaszok gyakorisági mintázatának életkori és nemi különbségei}

Célkitűzéseink megvalósításához, feltételezéseink teszteléséhez először a vizsgált pszichoszomatikus panaszok gyakoriságának életkori és nemi mintázatát jellemeztük. A vizsgált pszichoszomatikus panaszok gyakorisága mindkét nem esetében fokozódott az életkor előrehaladtával. Azonban a tüneteket átélők relatív gyakoriságának életkori mintázatában jelentős nemi különbségek igazolhatók, ugyanis a tüneteket nagy gyakorisággal átélők minden korcsoportban nagyobb volt a leányok esetében, mint fiú kortársaik körében. A vizsgált tünetek közül a pszichés tünetek (kedvetlenség, ingerlékenység, idegesség) fordultak elő a leggyakrabban mindkét nem esetében. Összességében az idegesség és a fáradtan ébredés tünetei voltak a vizsgált korintervallumban a leggyako- ribb pszichoszomatikus tünetek. A prepubertáskorúak (az első korcsoportba tartozó gyermekek) átlagosan 10\%-a élte át gyakran e tüneteket, azonban a posztpubertáskorú (a harmadik korcsoportba tartozó) fiúknak már közel a 30\%-a, a leányoknak viszont átlagosan már a 45\%-a panaszkodott e tünetekre.

A szomatikus tüneteket (fejfájás, hasfájás, szédülés) az első korcsoportba tartozó fiúk kevesebb, mint 5\%-a élte át hetente többször, és a posztpubertáskorú (a harmadik korcsoportba tartozó) fiúknak is csak a 6-9\%-át érintette gyakran (1. ábra). A pszichés tünetek (ingerlékenység, idegesség, kedvetlenség) közül az ingerlékenység tünetét átélő fiúk gyakorisági száma nem változott jelentősen az életkor előrehaladtával, átlagosan 20\%-uk élte át ezt a pszichoszomatikus tünetet. A kedvetlenséget gyakran átélők száma az első korcsoportba tartozó gyermekek körében tapasztalt átlagosan 5\%-ról a fiúk esetében a posztpubertáskorra 20\%-os gyakoriságig növekedett. Az idegesség tünete volt a leggyakrabban átélt pszichés tünet, mind a két nem esetén. Fiúk esetén a harmadik életkori korcsoportban 35\%-ig emelkedett az idegesség tünetét gyakran átélők száma. Az alvási nehézségek (elalvási nehézség, gyakori éjszakai felébredés, fáradtan ébredés) közül az elalvási nehézségre és a gyakori éjszakai felébredésre az első korcsoportba tartozó gyermekek 5\%-a panaszkodott, majd a második korcsoportban elérte a fiúk esetében a $15 \%$-os gyakoriságot. A két nem esetében a tünetek gyakoriságára panaszkodók száma már nem emelkedett jelentősen az életkor előrehaladtával. A fáradtan ébredés tünete a gyakoriságát tekintve elkülönült a többi alváspanasztól, az erre a tünetre panaszkodó fiúknál a gyakoriság 35\%-ig fokozódott a vizsgált korintervallum végére.

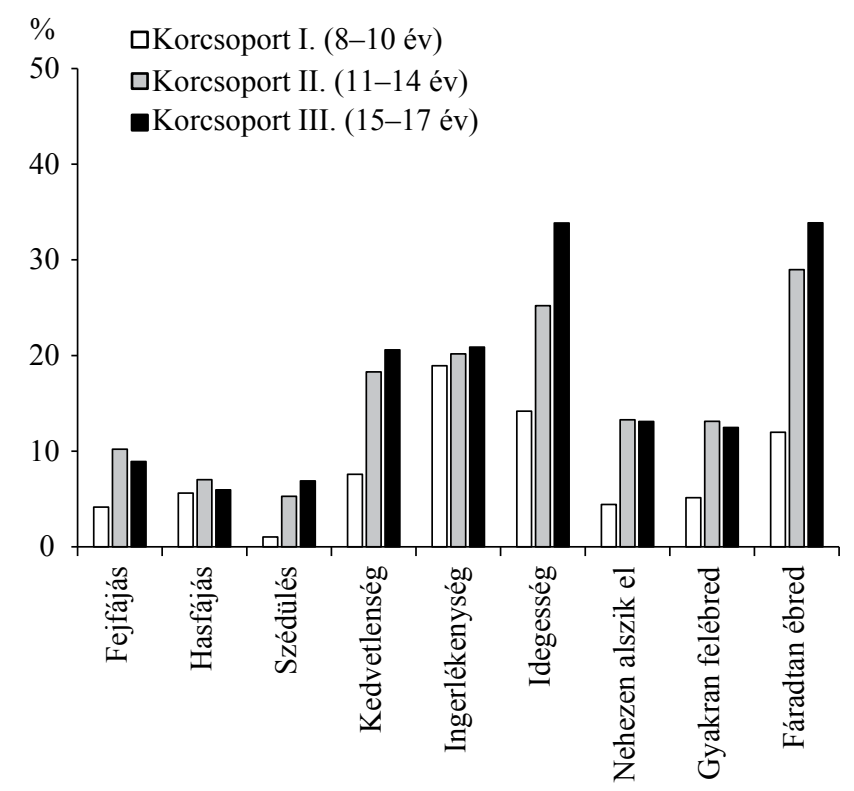

1. ábra

A vizsgált pszichoszomatikus tüneteket (hetente többször) átélők relatív előfordulási gyakoriságának (\%) életkori mintázata fiúknál 


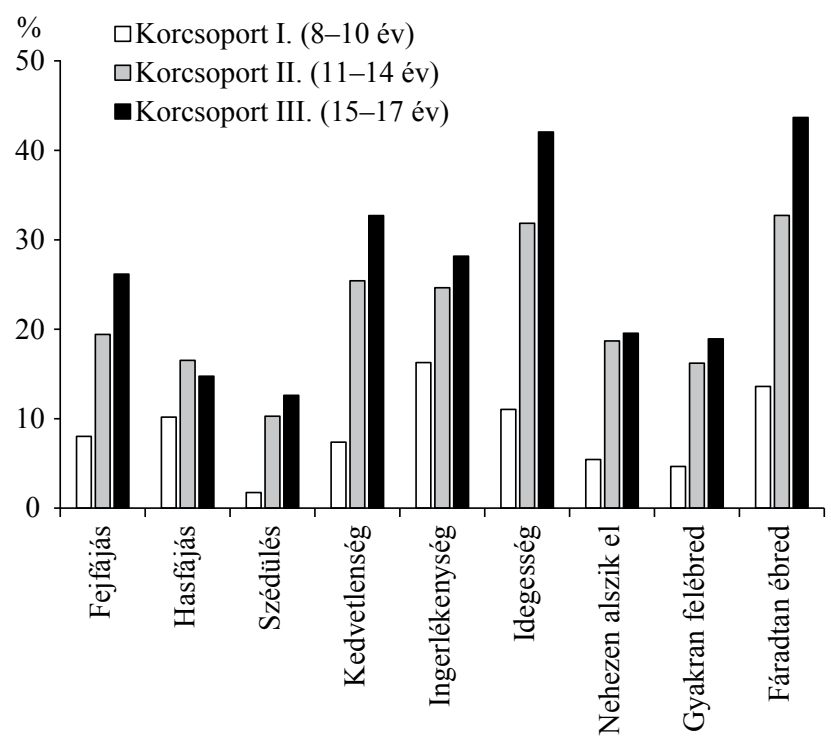

2. ábra

A vizsgált pszichoszomatikus tüneteket (hetente többször) átélők relatív előfordulási gyakoriságának (\%) életkori mintázata leányoknál

A szomatikus tüneteket gyakran átélő leányok első korcsoportra jellemző átlagosan 5-10\%-os előfordulása a szédülés és a hasfájás esetében a $15 \%$-os, míg a fejájás esetében a több, mint $25 \%$-os gyakoriságot is elérte. A pszichés tünetek közül a leányok esetében az ingerlékenységet gyakran átélők gyakorisága a fiúkéhoz hasonló mintázatot mutatott az első korcsoportban, majd az életkor előrehaladtával fokozatosan nőtt a 25-30\%-os gyakoriság eléréséig. A kedvetlenség tünete a fiúkkal ellentétben, a leányok esetében a $30 \%$-os gyakoriságot is elérte a posztpubertáskorú leányok korcsoportjában. Az idegesség tünetének gyakorisága leányoknál 40-45\%-ig emelkedett a harmadik korcsoportban. Az elalvási nehézség és a gyakori éjszakai felébredés tünete a harmadik korcsoportban elérte a $20 \%$-ot. A fáradtan ébredés tünetére gyakran panaszkodó leányok gyakorisága 45\%-ig fokozódott a vizsgált korintervallum végére (2. ábra).

Feltételezhető, hogy a két nem gyakorisági értékei közötti különbség hátterében biológiai, pszichés és viselkedésbeli tényezők kölcsönhatása áll, mely abban nyilvánul meg, hogy a leányok például érzelmileg sérülékenyebbek, érzékenyebben reagálnak a változásokra, könnyebben elfogadják egy betegség meglétét, és hatékonyan elmélyítik a betegségtudatot, s panaszaikról is készségesebben beszélnek.

\section{A pszichoszomatikus panaszok gyakorisága és az életmód, illetve a pszichoszociális státusz tényezôi közötti kapcsolatrendszer elemzése multinomiális logisztikus regressziós analizissel}

A szomatikus tünetek gyakorisága esetében a többtényezős logisztikus regressziós elemzés alapján megállapítást nyert, hogy a fiúknál a szubjektív egészségi állapot és a fizikai aktivitás mértéke, míg a leányoknál a testmagas- ság, a tápláltsági állapot, a testkép és az iskolai teljesítmény szoros kapcsolatban állt a vizsgált testi tünetek, azaz a fej-, hasfájás és szédülés gyakoriságával a vizsgált 8-17 évesek korosztályában ( $\chi^{2}$-próba - fiúk: $\mathrm{p}=0,015$, leányok: $\mathrm{p}=0,002$ ).

Az egészségi állapotukat jónak minősítő, illetve az átlagostól nagyobb mértékű fizikai aktivitást végző fiúk ritkábban éltek át testi tüneteket, mint egészségi állapotukat rossznak ítélő, illetve inaktív kortársaik. Ezzel szemben a leányoknál a nagyobb testmagasság, a rosszul táplált (alultáplált) tápláltsági állapot, valamint a jó tanulmányi eredmény és a pozitív testkép nagy valószínűséggel csökkentette a szomatikus panaszok gyakoriságát (2. táblázat).

A pszichés panaszok gyakoriságával a fiúk esetében a szubjektív egészségi állapot, a teljes énkép és a szocioökonómiai státusz, míg a leányoknál a szubjektív egészségi állapot, a tápláltsági állapot, a testkép és a teljes énkép, illetve az iskolai tanulmányi eredmény mutatott statisztikailag is igazolható kapcsolatot $\left(\chi^{2}\right.$-próba - fiúk:

2. táblázat |A szomatikus panaszok gyakoriságát befolyásoló tényezők logisztikus regressziós elemzés által becsült statisztikai mutatói a gyakori tünetek bekövetkezésének valószínúségére vonatkozó becslést elvégezve

\begin{tabular}{|c|c|c|c|}
\hline Magyarázó tényező & B & $\exp (B)$ & $\mathrm{p}$ \\
\hline \multicolumn{4}{|l|}{ Fiuk } \\
\hline \multicolumn{4}{|c|}{ Szubjektív egészségi állapot } \\
\hline$-\operatorname{rossz}$ & 2,170 & 2,622 & $\mathrm{p}<0,001$ \\
\hline - átlagos & 1,985 & 4,205 & $\mathrm{p}<0,001$ \\
\hline- jó $^{*}$ & - & - & - \\
\hline \multicolumn{4}{|l|}{ Fizikai aktivitási szint } \\
\hline - inaktív & 1,512 & 4,534 & 0,055 \\
\hline - átlagos & $-0,957$ & 0,384 & 0,140 \\
\hline - aktív* & - & - & - \\
\hline \multicolumn{4}{|l|}{ Leányok } \\
\hline Testmagasság $(\mathrm{cm})$ & $-0,783$ & 0,457 & 0,061 \\
\hline \multicolumn{4}{|l|}{ Tápláltsági állapot } \\
\hline - rosszul táplált* & - & - & - \\
\hline - normál & 2,323 & 6,701 & $\mathrm{p}<0,001$ \\
\hline - túlsúlyos & 1,957 & 3,161 & $\mathrm{p}<0,001$ \\
\hline - kövér & 1,915 & 2,084 & $\mathrm{p}<0,001$ \\
\hline \multicolumn{4}{|l|}{ Testkép-kategória } \\
\hline - jó & $-1,239$ & 0,290 & 0,046 \\
\hline - átlagos & $-0,783$ & 0,457 & 0,117 \\
\hline$-\operatorname{rossz} z^{*}$ & - & - & - \\
\hline \multicolumn{4}{|c|}{ Tanulmányi eredmény } \\
\hline - jó & $-1,393$ & 0,248 & 0,007 \\
\hline - átlagos & $-0,537$ & 0,585 & 0,180 \\
\hline$-\operatorname{rossz} z^{*}$ & - & - & - \\
\hline
\end{tabular}

$\mathrm{B}=$ regressziós együttható; $\exp (\mathrm{B})=$ esélyhányados; $\mathrm{p}=$ szignifikanciaszint (Wald-statisztika); * = referenciakategória 
$\mathrm{p}=0,010$, leányok: $\mathrm{p}<0,001 ; 3$. táblázat $)$. A jobb szubjektív egészségi állapotú, pozitív teljes énképü, illetve jó szocioökonómiai státuszú fiúk körében a pszichés panaszok ritkábban fordultak elő, mint átlagos vagy jó egészségi állapotú, átlagos vagy pozitív teljes énképú, átlagos vagy rossz szocioökonómiai hátterü kortársaiknál. Ezzel szemben a leányok rossz szubjektív egészségi állapotú,

3. táblázat A pszichés tünetek gyakoriságával szoros kapcsolatot mutató tényezők logisztikus regressziós elemzés által becsült statisztikai mutatói (a gyakori tünetek bekövetkezésének valószínúségére vonatkozó becslést elvégezve)

\begin{tabular}{|c|c|c|c|}
\hline Magyarázó tényező & $\mathrm{B}$ & $\exp (B)$ & $\mathrm{p}$ \\
\hline \multicolumn{4}{|l|}{ Fiúk } \\
\hline \multicolumn{4}{|c|}{ Szubjektív egészségi állapot } \\
\hline$-\operatorname{rossz}$ & 1,783 & 5,576 & $\mathrm{p}<0,001$ \\
\hline - átlagos & 1,716 & 2,838 & $\mathrm{p}<0,001$ \\
\hline- jó$^{*}$ & - & - & - \\
\hline \multicolumn{4}{|c|}{ Teljes énkép kategória } \\
\hline - jó & $-1,399$ & 0,247 & 0,011 \\
\hline - átlagos & $-1,174$ & 0,309 & 0,005 \\
\hline$-\operatorname{rossz} z^{*}$ & - & - & - \\
\hline \multicolumn{4}{|c|}{ Szocioökonómiai státusz } \\
\hline$-\operatorname{rossz}$ & 1,246 & 3,477 & 0,010 \\
\hline - átlagos & 0,842 & 2,320 & 0,057 \\
\hline$-\mathrm{jó}^{*}$ & - & - & - \\
\hline \multicolumn{4}{|l|}{ Leányok } \\
\hline \multicolumn{4}{|c|}{ Szubjektív egészségi állapot } \\
\hline$-\operatorname{rossz}$ & 1,644 & 1,387 & $\mathrm{p}<0,001$ \\
\hline - átlagos & 1,626 & 1,161 & $\mathrm{p}<0,001$ \\
\hline- jó $^{*}$ & - & - & - \\
\hline \multicolumn{4}{|l|}{ Tápláltsági állapot } \\
\hline - rosszul táplált* & - & - & - \\
\hline - normál & 1,534 & 4,591 & $\mathrm{p}<0,001$ \\
\hline - túlsúlyos & 1,594 & 8,385 & $\mathrm{p}<0,001$ \\
\hline - kövér & 1,785 & 5,655 & $\mathrm{p}<0,001$ \\
\hline \multicolumn{4}{|l|}{ Testkép-kategória } \\
\hline - jó & $-1,255$ & 0,285 & 0,067 \\
\hline - átlagos & $-1,471$ & 0,230 & 0,004 \\
\hline$-\operatorname{rossz}^{*}$ & - & - & - \\
\hline \multicolumn{4}{|c|}{ Teljes énkép kategória } \\
\hline - jó & $-2,704$ & 0,067 & $\mathrm{p}<0,001$ \\
\hline - átlagos & $-1,314$ & 0,269 & 0,006 \\
\hline$-\operatorname{rossz}{ }^{*}$ & - & - & - \\
\hline \multicolumn{4}{|c|}{ Tanulmányi eredmény } \\
\hline - jó & $-0,596$ & 0,551 & 0,321 \\
\hline - átlagos & $-0,909$ & 0,403 & 0,051 \\
\hline$-\operatorname{rossz} z^{*}$ & - & - & - \\
\hline
\end{tabular}

$\mathrm{B}=$ regressziós együttható; $\exp (\mathrm{B})$ = esélyhányados; $\mathrm{p}=$ szignifikanciaszint (Wald-statisztika); * = referenciakategória nem rosszul táplált tápláltsági állapotú, negatív testképú, negatív teljes énképú, illetve rossz tanulmányi eredményư alcsoportjaiban a vizsgált pszichés panaszok gyakorisága jelentősen nagyobb volt, mint az e tényezók alapján nem ezekbe a kategóriákba sorolt kortársaik körében (3. táblázat).

Az alvási nehézségek gyakorisága (nehezen tud elaludni, gyakran felébred éjjel) és a vizsgált életmódbeli, testszerkezeti tényezők közötti kapcsolatrendszer elemzése során megállapítást nyert, hogy a fiúknál a test relatíve nagy zsírtartalma, a rossz szubjektív egészségi állapot és a 10000 főnél kisebb lélekszámú lakóhely jelentősen növelte a vizsgált pszichoszomatikus panaszok nagyobb gyakoriságának valószínúségét ( $\chi^{2}$-próba - fiúk: $\mathrm{p}=$ 0,021 , leányok: $\mathrm{p}=0,011 ; 4$. táblázat). A leányoknál az alvászavarok gyakoriságával csak a kistérség gazdaságitársadalmi besorolása mutatott jelentős kapcsolatot, a hátrányos helyzetű kistérségekben élő leányok szignifikánsan gyakrabban élték át a vizsgált alvási nehézségeket, mint a nem hátrányos helyzetű településeken élő kortársaik (4. táblázat).

A fáradtan ébredés a gyakoriságát tekintve elkülönült a többi alvászavartól és a többi pszichoszomatikus tünettől, ezért külön elemeztük. A fáradtan ébredés panaszára az átlagostól nagyobb testtömegú leányok, illetve a rossz szubjektív egészségi állapotú fiúk panaszkodtak a leggyakrabban ( $\chi^{2}$-próba - fiúk: $\mathrm{p}=0,043$, leányok: $\mathrm{p}<0,001 ; 5$. táblázat $)$.

\section{4. táblázat $\mid$ Az alvási nehézségek (nem tud elaludni, éjjel gyakran felébred) gyakoriságával szoros kapcsolatot mutató tényezők logisztikus regressziós elemzés által becsült statisztikai mutatói (a gyakori tünetek bekövetkezésének valószínúségére vonatkozó becslést elvégezve)}

\begin{tabular}{|c|c|c|c|}
\hline Magyarázó tényező & B & $\exp (B)$ & $\mathrm{p}$ \\
\hline \multicolumn{4}{|l|}{ Fiúk } \\
\hline Életkor (év) & 0,519 & 1,681 & 0,001 \\
\hline Relatív zsírtömeg (\%) & 0,091 & 1,296 & 0,039 \\
\hline \multicolumn{4}{|l|}{ Településnagyság } \\
\hline - kevés lélekszámú & 1,196 & 3,308 & 0,007 \\
\hline - nagy lélekszámú* & - & - & - \\
\hline \multicolumn{4}{|c|}{ Szubjektív egészségi állapot } \\
\hline$-\operatorname{rossz}$ & 1,780 & 5,407 & $\mathrm{p}<0,001$ \\
\hline - átlagos & 1,712 & 2,741 & $\mathrm{p}<0,001$ \\
\hline- jó * $^{*}$ & - & - & - \\
\hline \multicolumn{4}{|l|}{ Leányok } \\
\hline Életkor (év) & 0,228 & 1,223 & 0,047 \\
\hline \multicolumn{4}{|c|}{$\begin{array}{l}\text { Kistérség gazdasági-társadalmi } \\
\text { besorolása }\end{array}$} \\
\hline - hátrányos & 0,764 & 2,148 & 0,028 \\
\hline - nem hátrányos* & - & - & - \\
\hline
\end{tabular}

$\mathrm{B}=$ regressziós együttható; $\exp (\mathrm{B})$ = esélyhányados; $\mathrm{p}=$ szignifikanciaszint (Wald-statisztika); * = referenciakategória 
5. táblázat A fáradtan ébredés pszichoszomatikus panasz (nem tud elalud ni, éjjel gyakran felébred) gyakoriságával szoros kapcsolatot mutató tényezók logisztikus regressziós elemzés által becsült statisztikai mutatói (a gyakori tünetek bekövetkezésének valószínűségére vonatkozó becslést elvégezve)

\begin{tabular}{llll}
\hline Magyarázó tényező & $\mathrm{B}$ & $\exp (\mathrm{B})$ & $\mathrm{p}$ \\
\hline $\begin{array}{l}\text { Fiúk } \\
\text { Szubjektív egészségi állapot }\end{array}$ & & & \\
- rossz & 1,850 & 1,824 & $\mathrm{p}<0,001$ \\
- átlagos & 1,835 & 1,902 & $\mathrm{p}<0,001$ \\
- jó & - & - & - \\
\hline Leányok & & & \\
Testtömeg $(\mathrm{kg})$ & 0,184 & 1,488 & 0,038 \\
\hline
\end{tabular}

$\mathrm{B}=$ regressziós együttható; $\exp (\mathrm{B})$ = esélyhányados; $\mathrm{p}=$ szignifikanciaszint (Wald-statisztika); * = referenciakategória

\section{Megbeszélés}

A hagyományos nyugati orvoslás célja a tünetek szervi okának felderítése. Gyermekek esetén ez a megközelítés csak korlátozottan alkalmazható. Az empirikus munkákból kiderül, hogy a funkcionális szomatikus tünetektől szenvedő gyermekek nagy része nem részesül megfelelő ellátásban. A tünetek iskolai hiányzáshoz vezethetnek, aminek negatív következményei lehetnek a fiatalok életére, mint például a szociális izoláció, a társas kapcsolatok elszegényedése, az iskolai teljesítmény romlása [26, 27].

A tanulmányok igazolják, hogy a felnőttkorban jelentkező funkcionális szomatikus tünetek gyökerei a gyermekkorig nyúlnak vissza $[28,29]$. A Brattberg és mtsai által végzett vizsgálatból kiderült, hogy a gyerekkorban jelentkező pszichoszomatikus tünetek nem átmeneti jellegűek, felnőttkorban folytatódhatnak, akár súlyosbodhatnak is, nehezen kezelhető pszichoszomatikus betegségek kialakulásához vezethetnek [30]. 1991-ben az akkor megvizsgált 8, 11 és 14 éves leányok $15 \%$-a, a fiúk $4 \%$-a panaszkodott hátfájásra, 40 és $20 \%$-uk fejfájásra. 2002-ben a már 21, 24, illetve 27 éves nők 59\%-ánál, a férfiak 39\%-ánál okozott problémát valamilyen pszichoszomatikus fájdalom.

Magni és mtsai 16 éves, hasfájással küzdő fiatalok egészségi állapotának változásait követték nyomon 10 éven keresztül, 26 éves korukig. Megfigyelték, hogy a tünetek 50\%-ukban megszüntek, 25\%-ukban azonban felnőttkorban is jelentkeztek. Az esetek 25\%-ában más pszichoszomatikus tünetek is megjelentek [31].

Az orvoshoz forduló felnőttek közel 50\%-ánál nem sikerül szervi okot azonosítani a tünetek hátterében [32]. A tünetek időben történő diagnosztizálása és kezelése a felnőttkori életminőséget jelentősen befolyásolja.

Vizsgálati eredményeinket összegezve elmondható, hogy az a kiindulási feltételezésünk, miszerint a vizsgált pszichoszomatikus panaszok gyakorisága az életkor előrehaladtával fokozódik a vizsgált életkori intervallum- ban, mindkét nem esetében igazolódott. A pszichoszomatikus panaszok mintegy a pszichoszociális stressz biomarkereként múködhetnek: ahogy az életkor előrehaladtával a gyermekek egyre nagyobb mértékü pszichoszociális stressznek vannak kitéve, úgy nő köreikben a pszichoszomatikus tünetek előfordulási gyakorisága is az életkorral. Oster tanulmányában a fejfájás előfordulási gyakoriságának csúcsa 12 éves korban volt, míg a hasfájás gyakorisága 9 éves korban tetőzött [33]. Eredményeink ezzel szemben azt mutatják, hogy míg a fiúknál valóban 12 éves kor körül tetőzött a gyakori fejfájás tünetét átélők száma, addig a leányoknál a görbe egy kisebb emelkedést mutat 11 éves kor körül a tünetek gyakoriságát illetően, de esetükben ezt követően végig növekszik a tüneteket gyakran átélő leányok száma. A hasfájás tünetét gyakran átélő fiúk és leányok előfordulási gyakorisága 12 éves kor körül érte el a legmagasabb értéket. Az egyes pszichoszomatikus panaszokat gyakran átélő gyermekek gyakorisági mintázatát tekintve a két nem között szintén jelentős különbséget tudtunk igazolni: a panaszokat a prepubertáskorú leányok átlagosan 5\%-kal, a pubertásés posztpubertáskorú leányok átlagosan 15-20\%-kal nagyobb gyakoriságban élték át, mint fiú kortársaik.

Vizsgálati eredményeink szintén igazolták azt a feltételezésünket, hogy a szubjektív egészségi állapot és a pszichoszomatikus panaszok gyakorisága között jelentős a kapcsolat: a rosszabb szubjektív egészségi állapot mindhárom pszichoszomatikus tünetcsoport nagyobb gyakoriságával járt együtt. A fiúknál a testi tünetek gyakoriságának valószínúségét a rossz szubjektív egészségi állapoton kívül a fizikai inaktivitás, a pszichés tünetek gyakoriságának valószínűségét a negatív önértékelés és a család átlagostól rosszabb szocioökonómiai státusza növelte. Az alvási zavarok gyakoriságának valószínúsége az életkorral fokozódott, illetve a nagyobb relatív zsírtömegú, 10000 lakosnál kevesebb lélekszámú településeken élő fiúknál volt a legnagyobb a valószínűsége az alvászavarok kialakulásának. Hangsúlyoznunk kell, hogy a leányoknál a szomatikus és pszichés tünetek gyakoriságának valószínúségét az alultáplált tápláltsági állapottól eltérő, tehát napjaink női szépségideáljától eltérő, akár még normál tápláltsági állapot is fokozta. Emellett a leányoknál a tünetek e két csoportjának valószínúségét még az iskolai sikertelenség és a negatív önértékelés is egyértelmúen növelte.

A leányok esetében az alvási nehézségek gyakorisága a posztpubertáskorúak körében, illetve a hátrányos helyzetű gazdasági-társadalmi kistérségekben volt a legnagyobb mértékü.

A fáradtan ébredés a gyakorisági mintázatát tekintve elkülönült a többi alvászavartól és az összes többi pszichoszomatikus tünettől, ezért külön elemeztük. A fáradtan ébredés tünetére az átlagostól nagyobb testtömegű leányok, illetve a rossz szubjektív egészségi állapotú fiúk panaszkodtak a leggyakrabban. 


\section{Következtetések}

A multinomiális logisztikus regressziós elemzés amellett, hogy feltárta azokat a pszichoszociális, életmódbeli és testszerkezeti tényezőket, amelyek összefüggést mutatnak a pszichoszomatikus tünetek gyakorisági mintázatával, lehetőséget adott olyan következtetések levonására is, mint (1) a rendszeresen végzett fizikai aktivitás a stresszel szembeni hatékony megküzdési stratégia, (2) a szubjektív egészségi állapot valóban egy pubertáskorban különösen érzékeny, a pszichoszociális stresszel szemben sérülékeny, komplex emocionális, fizikai, mentális, szociális és viselkedésbeli tényezőket magában foglaló funkcionális képesség és jólléti állapot, (3) nem elhanyagolható tényező a pszichoszomatikus tünetek előfordulási gyakoriságának tekintetében a lakóhely gazdasági-társadalmi besorolása (a közoktatási intézményrendszerek megléte vagy hiánya, az egészségügyi ellátás minősége, kulturális, rekreációs és szórakozási lehetőségek, az urbanizáltság foka, a szociálpolitikai helyzet, a demográfiai viszonyok, a foglalkoztatottság mértéke stb.), (4) meghatározó a család szocioökonómiai státusza is (például az, hogy van-e a családnak autója, hatással van a gyermek iskolaválasztására, szociális kapcsolataira, hogy van-e saját szobája, kihat az alvás mennyiségére és minőségére stb.).

Jól látszik, hogy milyen nehezen megfogható, mennyi tényező által befolyásolt, multidimenziós témakör a prepubertás, a pubertás és a posztpubertás időszakában vizsgált testi-lelki egészség.

Anyagi támogatás: A kutatás az OTKA K 76849. számú pályázatának anyagi támogatásával valósult meg.

Szerzői munkamegosztás: B. É., Zs. A.: A vizsgálatok végzése a Második Országos Növekedésvizsgálat keretein belül. F. P., A. D.: A közleményhez szükséges szakirodalmi háttér áttekintése. B. É., Zs. A.: A statisztikai elemzések elvégzése, valamint a Minta és a Módszer fejezet megírása. F. P.: A Vizsgálati eredmények és értékelésük és a Következtetések fejezet elkészítése. B. É., Zs. A., F. P., A. D.: A kézirat végső áttekintése. A cikk végleges változatát valamennyi szerző elolvasta és jóváhagyta.

Érdekeltségek: A szerzőknek nincsenek érdekeltségeik.

\section{Irodalom}

[1] Pikó B, Barabás K, Boda K. Frequency of common psychosomatic symptoms and its influence on self-perceived health in a Hungarian student population. Eur J Public Health 1997; 7: 243-247.

[2] Larsson, BS. Somatic complaints and their relationships to depressive symptoms in Swedish adolescents. J Child Psychol Psychiatry 1991; 32: 821-832.

[3] Murberg TA, Bru, E. School-related stress and psychosomatic symptoms among Norwegian adolescents. School Psychol Int. 2004; 25: 317-332.
[4] Aro H, Paronen O, Aro S. Psychosomatic symptoms among 14-16 year old Finnish adolescents. Soc Psychiatry 1987; 22: $171-176$

[5] Brill SR, Patel DR, MacDonald E. Psychosomatic disorders in pediatrics. Indian J Pediatr. 2001; 68: 597-603.

[6] Knishkowy B, Palti H, Tima, C, et al. Symptom clusters among young adolescents. Adolescence 1995; 30: 351-362.

[7] Egger HL, Angold A, Costello, EJ. Headaches and psychopathology in children and adolescents. J Am Acad Child Adolesc Psychiatry 1998; 37: 951-958.

[8] Alfvén G. The covariation of common psychosomatic symptoms among children from socio-economically differing residential areas: an epidemiological study. Acta Paediatr. 1993; 82: 484-487.

[9] Hyams JS, Burke G, Davis PM, et al. Abdominal pain and irritable bowel syndrome in adolescents: a community-based study. J Pediatr. 1996; 129: 220-226.

[10] Kristjánsdóttir G. Prevalence of pain combinations and overall pain: a study of headache, stomach pain and back pain among schoolchildren. Scand J Soc Med. 1997; 25: 58-63.

[11] Berntsson LT, Köhler L, Gustafsson JE. Psychosomatic complaints in schoolchildren: a Nordic comparison. Scand J Public Health 2001; 29: 44-54.

[12] Ibeziako P, Bujoreanu S. Approach to psychosomatic illness in adolescents. Curr Opin Pediatr. 2001; 23: 384-389.

[13] Binder LM, Campbell KA. Medically unexplained symptoms and neuropsychological assessment. J Clin Exp Neuropsychol. 2004; 26: 369-392

[14] Bodzsár É, Zsákai A. Body developmental status of Hungarian children and adolescents. Hungarian National Growth Study 2003-2006. [Magyar gyermekek és serdülők testfejlettségi állapota. Országos Növekedésvizsgálat 2003-2006.] Plantin Kiadó, Budapest, 2012. [Hungarian]

[15] Zsákai A, Bodzsár É. Subjectiv health status in relation to nutritional status in children aged between 7-18 years. [A szubjektív egészségi és a tápláltsági státusz közötti kapcsolat 7-18 éves gyermekeknél.] Anthrop Közl. 2012; 53: 101-114. [Hungarian]

[16] Weiner JS, Lourie JA. Human biology. A guide to field methods. IBP Handbook No. 9. Blackwell Scientific, Oxford, 1969

[17] Bodzsar EB. Maturation, body composition and mental performance. Acta Med Auxol. 2001; 33: 5-12.

[18] Drinkwater DT, Ross WD. Anthropometric fractionation of body mass. In: Kinanthropometry II. Univ. Park Press, Baltimore, MD, 1980; pp. 178-189.

[19] Haugland S, Wold B, Stevenson J, et al. Subjective health complaints in adolescence. A cross-national comparison of prevalence and dimensionality. Eur J Public Health 2001; 11: 4-10.

[20] Cole TJ, Bellizzi MC, Flegal KM, et al. Establishing a standard definition for child overweight and obesity worldwide: international survey. Br Med J. 2000; 320: 1240.

[21] Cole TJ, Flegal KM, Nicholls D, et al. Body mass index cut offs to define thinness in children and adolescents: international survey. Br Med J. 2007; 335: 194.

[22] Cantril H. The pattern of human concerns. Rutgers University Press, New Brunswick, NJ, 1965.

[23] Hollingshead AA. Four-factor index of social status. Yale University, New Haven, CT, 1975.

[24] Fitts WH. Tennessee self-concept scale. Counselor recordings and tests. Nashville, TE, 1964.

[25] Dévai M, Sipos M. Tennessee self-concept scale. [Tennessee-féle énkép skála.] Országos Pedagógiai Intézet, Budapest, 1986. [Hungarian]

[26] Bernstein GA, Massie ED, Thuras, PD, et al. Somatic symptoms in anxious-depressed school refusers. J Am Acad Child Psychiatry 1997; 36: 661-668.

[27] Vannatta K, Gartstein MA, Short A, et al. A controlled study of peer relationships of children surviving brain tumors: teacher, peer, and self ratings. J Pediatr Psychol. 1998; 23: 279-287. 
[28] Campo JV, Garber J. Somatization. In Ammerman RT, Campo JV. (eds.) Handbook of pediatric psychology and psychiatry: Psychological and psychiatric issues in the pediatric setting. Allyn and Bacon, Boston, MA, 1998; pp. 137-161.

[29] Fritz GK, Fritsch S, Hagino O. Somatoform disorders in children and adolescents: a review of the past 10 years. J Am Acad Child Adolesc Psychiatry 1997; 36: 1329-1338.

[30] Brattberg G. Do pain problems in young school children persist into early adulthood? A 13-year follow-up. Eur J Pain 2004; 8: 187-199.

[31] Magni G, Pierri M, Donzelli F. Recurrent abdominal pain in children: a long-term follow-up. Eur J Pediatr. 1987; 146: 72-74.
[32] Nimnuan C, Hotopf M, Wessely S. Medically unexplained symptoms: an epidemiological study in seven specialities. J Psychosom Res. 2001; 51: 361-367.

[33] Oster, J. Recurrent abdominal pain, headache and limb pains in children and adolescents. Pediatrics 1972; 50: 429-436.

(Zsákai Annamária dr., Budapest, Pázmány Péter sétány 1/C, 1117 e-mail: zsakaia@elte.hu)

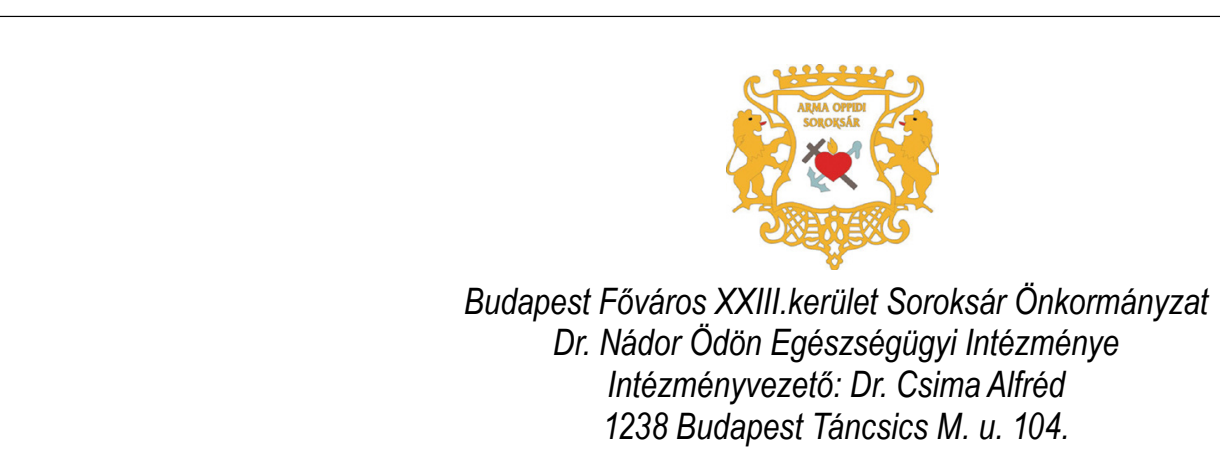

\section{A Dr. Nádor Ödön Egészségügyi Intézmény tüdőgyógyász szakorvost \\ keres heti 2 óra rendelési időre személyes közreműködőszerződéssel}

A munkavégzés helye: Budapest, 1238 Soroksár, Táncsics M. u. 104.

Feladatok:

- szakorvosi feladatok ellátása szerződés keretében heti 2 óra rendelési időre a jogszabályokban meghatározottaknak és szakmai kompetenciáknak megfelelően, a szakmai protokollok, irányelvek és módszertani útmutatók alapján a felnőtt soroksári lakósók részére.

A szerződés óradijas, számla ellenében történő 15 napos kifizetéssel.

Pályázati feltételek:

- egyetem, általános orvosi diploma, tüdőgyógyászati szakvizsga

- érvényes müködési engedély,

- kamarai tagság,

- büntetlen elóélet,

- egészségügyi alkalmasság.

A pályázat benyújtásának határideje: folyamatos

A pályázathoz csatolandó igazolások:

- szakmai önéletrajz

- iskolai, egyetemi, szakvizsga dokumentumok hiteles másolata

- érvényes müködési nyilvántartási igazolás

- MOK tagsági igazolás

A pályázatok benyújtásának módja:

Postai úton, a pályázatnak a Budapest Főváros XXIII. ker. Soroksár Önkormányzatának Dr. Nádor Ödön Egészségügyi Intézménye címére történő megküldésével (1238 Budapest, Soroksár, Táncsics M. u. 104.).

Elektronikus úton Pákáné Csehi Réka vezető asszisztens részére a pakane.csehi.reka@eszi23.hu E-mail címen keresztül

Budapest, 2019. február 25.

Dr. Csima Alfréd

intézményvezető föorvos

A cikk a Creative Commons Attribution 4.0 International License (htps://creativecommons.org/licenses/by/4.0/) feltételei szerint publikált Open Access közlemény. (SID_1) 